\title{
Tropical Signalgrass Control in Seashore Paspalum
}

\author{
Research Article
}

Volume 1 Issue 1- 2020

\begin{abstract}
Author Details
Timothy L. Stoudemayer, Lambert B McCarty ${ }^{\star}$, Robert B Cross

Department of Plant and Environmental Sciences, Clemson University, USA

*Corresponding author

Lambert B McCarty, Department of Plant and Environmental Sciences, Clemson University, 130 McGinty Court, Clemson, SC 29634-0310, USA
\end{abstract}

Article History

Received: November 09, 2020 Accepted: November 23, 2020 Published: November 24, 2020

\begin{abstract}
Tropical signalgrass (Urochloa subquadripara) is a mat-forming grass with relatively coarse texture. It is characterized by hairy sheaths and leaf blades plus a short fringe of hair present on the ligule. Tropical signalgrass control in Florida has been challenging for turf managers, in part, due to monosodium methanearsonate (MSMA) restrictions. Previous research indicates fall herbicide applications to be more effective than summer applications; however, fall applications typically do not allow turfgrass adequate time to fill in bare spots prior to winter. Two studies were conducted on seashore paspalum (Paspalum vaginatum) roughs at The Oaks golf course in Osprey, FL in summer 2019 comparing single and combination treatments of amicarbazone, carfentrazoneethyl, sulfentrazone, flazasulfuron, and quinclorac for control of tropical signalgrass. All treatments were applied with a non-ionic surfactant at $0.25 \% \mathrm{v} / \mathrm{v}$. In both studies a sequential application of each treatment was made 21 days after initial treatment (DAIT). Rating dates were 4 June, 25 June, 16 July, and 13 August, corresponding to 0, 21, 42, and 70 DAIT, respectively. In study one, 10 weeks after initial treatment (WAIT), amicarbazone + carfentrazone-ethyl + sulfentrazone at $0.23+0.0076+0.068 \mathrm{lb}$ ai/acre $(0.26+0.0085$ $+0.076 \mathrm{~kg}$ ai/ha), respectively, provided best control ( $\sim 60 \%)$. For study two, at 6 and 10 WAIT, tropical signalgrass control of $>50 \%$ was not achieved. Overall, long-term postemergence control of tropical signalgrass with summer applications of herbicides tested was incomplete, even with multiple applications; however, amicarbazone + carfentrazone-ethyl + sulfentrazone showed potential as a control option.
\end{abstract}

Keywords: Amicarbazone, carfentrazone-ethyl, flazasulfuron, Paspalum vaginatum, POST herbicide, quinclorac, sulfentrazone, sulfosulfuron, turfgrass, Urochloa subquadripara, weed control

\section{Introduction}

Tropical signalgrass (Urochloa subquadripara (Trin.) R.D. Webster) is a warm-season perennial grass weed invasive in well-maintained turf along coastal areas of the Gulf States in the United States and especially throughout Florida [1]. Tropical signalgrass is mat-forming, stoloniferous, and coarsely textured grass that disrupts the uniformity of turfgrasses [1]. Tropical signalgrass has hairy leaf blades and leaf sheaths, with a distinct fringe of hairs present on the ligule. Seashore paspalum (Paspalum vaginatum Swartz.) is a desirable playing surface for golf courses throughout Florida, mainly due to its salt tolerance. However, few pesticides are labelled specifically for use on it; therefore, weed control can be problematic [2]. If tropical signalgrass infests a seashore paspalum golf course, it is clearly visible due to differences in texture and color; this is not only aesthetically displeasing but disrupts playability as well [1].

In 2013, organic arsenical herbicides were banned for turfgrass use in Florida [3]. Possible replacements for organic arsenical herbicides such as MSMA for tropical signalgrass control in bermudagrass (Cynodon dactylon) have been investigated [4]. Results indicated sulfentrazone + imazethapyr; thiencarbazone-methyl + foramsulfuron + halosulfuronmethyl; and amicarbazone, all provided $>98 \%$ control; however, this study was conducted in bermudagrass and few postemergence (POST) herbicides labelled for bermudagrass are also labelled for seashore paspalum. This study was also conducted in the fall as bermudagrass was transitioning into dormancy (or slowed growth in subtropical regions), creating voids which would not recover until the spring. Being 
as seashore paspalum is also a warm season turfgrass, these previously mentioned complications would parallel from bermudagrass to seashore paspalum. This is highly undesirable as bare patches are not aesthetically pleasing, and they can also disrupt playability [4]. Also, for courses wishing to overseed with ryegrass (Lolium sp.) to provide late fall, winter, and early spring color, many of these herbicides have extended replant restrictions. Cross et al. [5] conducted a study to evaluate various herbicides for replacement of organic arsenical herbicides for tropical signalgrass control in bermudagrass and many of the herbicides evaluated were not safe on seashore paspalum. Amicarbazone was tested in this study, and $>97 \%$ tropical signalgrass control was observed at 12 weeks after initial treatment (WAIT). This study was conducted in the fall of both years; therefore, reinforcing that fall applications are generally more effective for this perennial weed than spring applications using same chemicals at the same rates. Due to seashore paspalum having intolerance to many postemergence herbicides, many of these previous studies were scrutinized closely to determine the treatment list for both experiments in this manuscript.
The objectives of these studies are to evaluate various POST herbicidal control options and application timing for tropical signalgrass that has infested seashore paspalum.

\section{Materials and Methods}

Two field experiments were conducted in the summer 2019 at The Oaks Club golf course, Osprey, FL (Lat. 27.2001 $\mathrm{N}$, long. $82.4839^{\circ} \mathrm{W}$ ) on seashore paspalum roughs to evaluate POST tropical signalgrass control. Soil profile at this course was fine sand and loamy sand marine deposits. Two separate studies were involved (Tables 1 and 2). For both, initial applications were made on 4 June 2019, with repeat applications 25 June 2019. Plots were located in roughs and the turfgrass was maintained at a mowing height of two inches $(5 \mathrm{~cm})$ and irrigated as needed to prevent drought stress. At the initiation of the first study, mean and standard deviation of tropical signalgrass infestation was $88.9 \%$ and $11.3 \%$, respectively. For the second study, initial tropical signalgrass infestation mean and standard deviation was $54 \%$ and $20.95 \%$, respectively.

Table 1: Herbicides and their rates applied twice, at zero and three weeks after initial treatment (WAIT), and subsequent tropical signalgrass control in seashore paspalum ratings for study one.

\begin{tabular}{|c|c|c|c|c|}
\hline Treatment $^{\mathrm{z}}$ & \multicolumn{3}{|c|}{ Rate $\left(\mathrm{lb}\right.$ ai/acre) $^{\mathrm{y}}$} & \multicolumn{3}{|c|}{ Tropical signalgrass control (\%) $)^{\mathrm{x}, \mathrm{w}}$} \\
\hline Nontreated control & & $3 \mathrm{WAIT}$ & 6 WAIT & $10 \mathrm{WAIT}$ \\
\hline Amicarbazone & -- & $0 \mathrm{~b}$ & $0 \mathrm{c}$ & $0 \mathrm{c}$ \\
\hline Amicarbazone & 0.14 & $12: 00 \mathrm{AM}$ & $36 \mathrm{~b}$ & $20 \mathrm{bc}$ \\
\hline Amicarbazone + carfentrazone-ethyl + sulfentrazone & $0.14+0.0047+0.043$ & $16 \mathrm{a}$ & $49 \mathrm{ab}$ & $30 \mathrm{ab}$ \\
\hline Amicarbazone + carfentrazone-ethyl + sulfentrazone & $0.23+0.0047+0.043$ & $17 \mathrm{a}$ & $76 \mathrm{a}$ & $48 \mathrm{ab}$ \\
\hline Amicarbazone + carfentrazone-ethyl + sulfentrazone & $0.14+0.0076+0.068$ & $18 \mathrm{a}$ & $61 \mathrm{ab}$ & $39 \mathrm{ab}$ \\
\hline Amicarbazone + carfentrazone-ethyl + sulfentrazone & $0.23+0.0076+0.068$ & $23 \mathrm{a}$ & $81 \mathrm{a}$ & $59 \mathrm{a}$ \\
\hline
\end{tabular}

${ }^{\mathrm{z}}$ All treatments included a non-ionic surfactant at $0.25 \% \mathrm{v} / \mathrm{v} ; 1 \mathrm{lb} / \mathrm{acre}=1.1209 \mathrm{~kg} / \mathrm{ha}$.

${ }^{y}$ Initial applications were made 4 June 2019, followed by sequential applications of the same rates on 25 June 2019.

xTropical signalgrass control was visually evaluated on a $0 \%$ to $100 \%$ scale $(0=$ no injury to tropical signalgrass, $100 \%=$ complete plant death). ${ }^{\text {w}}$ Column values followed by different letters are significantly different according to Fisher's least significant difference (LSD) test at $\mathrm{P}<0.05$.

Table 2: Herbicides and their rates applied twice, at zero and three weeks after initial treatment (WAIT), and subsequent tropical signalgrass control ratings in seashore paspalum for study two.

\begin{tabular}{|c|c|c|c|}
\hline \multirow[t]{2}{*}{ Treatment $^{2}$} & \multirow[t]{2}{*}{ Rate $(\mathrm{lb} / \mathrm{acre})^{\mathrm{y}}$} & \multicolumn{2}{|c|}{ Tropical signalgrass control $(\%)^{\mathrm{x}, \mathrm{w}}$} \\
\hline & & 6 WAIT & 10 WAIT \\
\hline Nontreated Control & --- & $0 \mathrm{ab}$ & $0 \mathrm{nsv}$ \\
\hline Amicarbazone & 0.14 & $41 \mathrm{a}$ & 29 \\
\hline Flazasulfuron & 0.048 & $1 \mathrm{ab}$ & 13 \\
\hline Quinclorac & 0.75 & $1 \mathrm{ab}$ & 4 \\
\hline Sulfosulfuron & 0.073 & $3 \mathrm{ab}$ & 6 \\
\hline Carfentrazone-ethyl + sulfentrazone & $0.0057+0.051$ & $5 \mathrm{ab}$ & 8 \\
\hline Amicarbazone + flazasulfuron & $0.14+0.048$ & $40 \mathrm{a}$ & 34 \\
\hline Amicarbazone + sulfosulfuron & $0.14+0.073$ & $7 \mathrm{ab}$ & 29 \\
\hline Amicarbazone + quinclorac & $0.14+0.75$ & $22 \mathrm{ab}$ & 13 \\
\hline Amicarbazone + carfentrazone-ethyl + sulfentrazone & $0.14+0.0057+0.051$ & $8 \mathrm{ab}$ & 34 \\
\hline Carfentrazone-ethyl + sulfentrazone + flazasulfuron & $0.0057+0.051+0.048$ & $1 \mathrm{ab}$ & 5 \\
\hline Carfentrazone-ethyl + sulfentrazone + sulfosulfuron & $0.0057+0.051+0.073$ & $1 \mathrm{ab}$ & 8 \\
\hline Carfentrazone-ethyl + sulfentrazone + quinclorac & $0.0057+0.051+0.75$ & $4 \mathrm{ab}$ & 23 \\
\hline Flazasulfuron + quinclorac & $0.048+0.75$ & $0 \mathrm{~b}$ & 0 \\
\hline Sulfosulfuron + quinclorac & $0.073+0.75$ & $1 \mathrm{ab}$ & 0 \\
\hline
\end{tabular}

${ }^{\mathrm{z}}$ All treatments included a non-ionic surfactant at $0.25 \% \mathrm{v} / \mathrm{v} ; 1 \mathrm{lb} / \mathrm{acre}=1.1209 \mathrm{~kg} / \mathrm{ha}$.

yInitial applications were made 4 June 2019, followed by sequential applications of the same rates on 25 June 2019.

${ }^{x}$ Tropical signalgrass control was visually evaluated on a $0 \%$ to $100 \%$ scale $(0=$ no injury to tropical signalgrass, $100 \%=$ complete plant death).

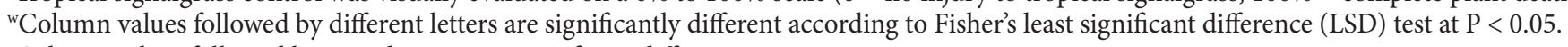

${ }^{v}$ Column values followed by ns indicates non-significant differences. 
Treatment rates and timings are presented in Tables 1 and 2. All treatments were applied with a carbon dioxide $\left(\mathrm{CO}_{2}\right)$-pressurized backpack sprayer calibrated to deliver $20 \mathrm{gal} / \mathrm{acre}(187 \mathrm{~L} / \mathrm{ha})$ through flat-fan nozzles (TeeJet 8003; Spraying Systems Co., Wheaten, IL). Plots were $1.5 \times 1.5 \mathrm{~m}$ with four replications using randomized complete block design. Tropical signalgrass density and percent control ratings were recorded at 3, 6 and 10 weeks after initial treatment (WAIT). Percent tropical signalgrass control was visually evaluated on a $0 \%$ to $100 \%$ scale $(0=$ no injury to tropical signalgrass, $100=$ complete plant control). Data were analyzed to evaluate main effects and treatment interactions. Mean comparisons between treatments were performed using Fisher's least significant difference (LSD) test. All statistical analyses were conducted using JMP Pro software (Version 12; SAS Institute, Cary, NC). Significant effects and differences were based on $\alpha=0.05$.

\section{Results and Discussion}

In study one (Table 1), 75\% control was achieved 6 WAIT with amicarbazone + carfentrazone-ethyl + sulfentrazone at the highest rate of $0.23+0.0076+0.068 \mathrm{lb} / \mathrm{acre}$, respectively, and amicarbazone + carfentrazone-ethyl + sulfentrazone at $0.23+0.0047+0.043 \mathrm{lb}$ ai/ acre $(0.26+0.0085+0.076 \mathrm{~kg}$ ai/ha), respectively. All other treatments provided $<70 \%$ at 6 WAIT, and at 10 WAIT, all treatments provided $<60 \%$ control. In study two, $>50 \%$ control was not achieved from any treatment at any rating date. In terms of turfgrass injury, across all treatments for both studies, unacceptable injury ( $>30 \%)$ was not observed. McCarty and Estes [4] conducted field studies evaluating various POST herbicides, specifically thiencarbazone-methyl + foramsulfuron, + halosulfuron-methyl, and they noted during the transition from spring to summer, two to five spot-treatment applications were required to achieve $>90 \%$ control. However, when two fall applications were made with thiencarbazone-methyl + foramsulfuron, + halosulfuron-methyl, tank mixed with amicarbazone, $100 \%$ control was achieved through May, and 98\% control through June. Although a number of these treatments achieved $>90 \%$ control; the study was conducted on bermudagrass and many of the herbicides used in this study would injure seashore paspalum to unacceptable levels and/or for extended time.

In 2006, a study was conducted in seashore paspalum to determine the tolerance of common POST herbicides [6]. Bentazon, clopyralid, dicamba, halosulfuron, imazaquin, mecoprop + 2,4-D + dicamba, metsulfuron, and quinclorac all caused $<15 \%$ injury 7 DAIT, and $<10 \%$ at 15 DAIT, all of which are below the threshold (30\%). Clethodim, sethoxydim, ethofumesate, imazapic, and trifloxysulfuron-sodium were rated between $33 \%$ and $71 \%$ turf injury [6]. Several of these herbicides are rated for broadleaf weeds; however, this study reinforces the difficulty of selecting and using herbicides that will not injure seashore paspalum above threshold $(<30 \%)$. In 2019 , Lindsey conducted a study to evaluate POST herbicide options for bermudagrass encroachment into seashore paspalum [7]. Plots were rated as \% green color, 0 being completely brown or white, and 100 being maximum attainable green color. In one trial, topramezone individually applied to 'SeaDwarf' seashore paspalum at $0.02 \mathrm{lb}$ ai/acre $(0.022 \mathrm{~kg} \mathrm{ai} / \mathrm{ha})$ had the worst injury on seashore paspalum with $\sim 23$ percent green color at 14 DAIT; however was recovered to $\sim 94$ percent green color by 22 DAIT; however, when replicated in containers, bermudagrass recovered to $97 \%$ at 21 DAIT following an initial rating of $\sim 20 \%$ at 7 DAIT [7]. This study is further proof of the scarceness of pesticides labelled for seashore paspalum that can control warmseason grassy weeds. POST control of goosegrass (Eleusine indica (L.) Gaertn.) and herbicide safety in bermudagrass and seashore paspalum were conducted in Griffin, GA in 2010 and 2011 [8]. A 'Sea Isle 1' seashore paspalum fairway was used to rate injury from individual and sequential applications. A sequential application of a tank mixture of nicosulfuron + sulfentrazone at $0.098+0.37 \mathrm{lb}$ ai/acre $(0.11+0.41$ $\mathrm{kg}$ ai/ha), respectively, showed the greatest injury at $54 \% 4$ WAIT; however, all treatments recovered to $<10 \%$ injury by 9 WAIT [8].

In 2004, a study was conducted to find suitable pre-emergent (PRE) and POST options for tropical signalgrass [9]. Both greenhouse trials and field trials were utilized to investigate herbicidal options. In the POST field trial, no single herbicide or combination of asulam, ethofumesate, quinclorac or CGA $362622 \mathrm{had}>50 \%$ control of tropical signalgrass at any rating date [9]. However, in the greenhouse trial, seedlings at the two-, four-, six- and eight-leaf stage were tested with asulam (0.98 lb ai/acre, $1.1 \mathrm{~kg} / \mathrm{ha})$, CGA 362622 (0.044 lb ai/acre, 0.049 $\mathrm{kg} / \mathrm{ha})$, ethofumesate $(1.5 \mathrm{lb}$ ai/acre, $1.68 \mathrm{~kg}$ ai/ha) and imazaquin $(0.54 \mathrm{lb}$ ai/acre, $0.60 \mathrm{~kg} / \mathrm{ha})$, all had $>98 \%$ control at the two-leaf stage [9]. Asulam, CGA 362622, and imazaquin had $>97 \%$ at the eight-leaf stage [9]. Quinclorac ( $0.54 \mathrm{lb}$ ai/acre, $0.60 \mathrm{~kg}$ ai/ha) was tested, and at the eight-leaf stage had $61 \%$ control of tropical signalgrass [9]. In the PRE trial, many herbicides provided acceptable control; however due to variability between years and sod types, many differences become insignificant [9]. Treatments that stands out across all years, sod types, and rating dates was benefin + oryzalin $(3.0 \mathrm{lb}$ ai/acre $3.36 \mathrm{~kg} / \mathrm{ha})$, and imazapic + 2,4-D (0.37 lb ai/acre, $0.41 \mathrm{~kg} / \mathrm{ha})$ at $>75 \%$ control at 11 WAIT $[9,10]$.

Future research should include evaluating selective bioherbicidal options, evaluation of herbicides that provide long-term tropical signalgrass control, and additional herbicide options for spring and summer applications for tropical signalgrass control in seashore paspalum.

\section{Acknowledgement}

Technical contribution No. 6924 of the Clemson University Experiment Station.

\section{References}

1. McCarty LB, DW Hall (2018) Common weeds and wildflowers. Clemson Univ. Public Serv., Clemson, SC: Publ. 96.

2. McCarty LB (2018) Golf turf management. CRC Press, Boca Raton, FL. Pp. 732.

3. US Environmental Protection Agency (2019) Monosodium methanearsonate (MSMA), an organic arsenical. 23 Aug. 2020.

4. McCarty LB, AG Estes (2014) Tropical signalgrass control. Golf Course Mgt. 82(4): 80-85.

5. Cross RB, LB McCarty, AG Estes (2016) Postemergence tropical signalgrass (Urochloa subquadripara) control with nonorganic arsenical herbicides. Weed Technol 30(3): 815-821.

6. Unruh JB, DO Stephenson IV, BJ Brecke, LE Trenholm (2006) Tolerance of 'Salam' seashore paspalum (Paspalum vaginatum) to postemergence herbicides. Weed Technol 20(3): 612-616.

7. Lindsey AJ, J DeFrank, Z Cheng (2019) Seashore paspalum and bermudagrass response to spray applications of postemergence herbicides. HortTechnology 29(3): 251-257.

8. McCullough PE, DG Barreda, P Raymer (2012) Nicosulfuron use with foramsulfuron and sulfentrazone for late summer goosegrass (Eleusine indica) control in bermudagrass and seashore paspalum. Weed Techno 26(2): 376-381.

9. Teuton TC, JB Unruh, BJ Brecke, GE Macdonald, GL Miller, et al. (2004) Tropical signalgrass (Urochloa subquadripara) control with preemergence- and postemergence- applied herbicides 1 . Weed Technol 18(2): 419-425.

10. https://www.epa.gov/ingredients-used-pesticide-products / monosodium-methanearsonate-msma-organic-arsenical 